\title{
等変位孔内載荷試験における弾性厳密解 を用いた岩盤変形係数の算定
}

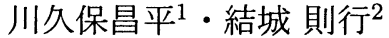 \\ ${ }^{1}$ 正会員 博士 (工) 川崎地質株式会社 関東支社 ( $\bar{T}$ 180-8837 東京都港区三田二丁目 11-15) \\ ${ }^{2}$ 正会員 修士 (工) 川崎地質株式会社 中部支店 ( $\bar{T}$ 465-0095 愛知県名古屋市東区高社 1-266)
}

現在，ボアホールジャッキ試験の評価に用いられる変形係数算定式は, 当初 Goodman が導出したものに Hustrulid P Amadei らが幾らか修正を加えてきたが，これらはいずれも第一種境界值問題として導かれた近似 式である. 本論文では, 混合境界值問題から導かれる厳密解より等変位載荷条件としての厳密な算定式を求め る. 後半の数值計算例では応力, 変位および変形倸数の算定係数における従来の近似解との相違を示す.

Key Words : bore-hole jack test, the first and mixed fundamental problem, rock mass deformability

\section{1. 緒 言}

ボーリング孔を利用した原位置での孔内載荷試験に はゴムチューブを膨張させて孔壁を等圧に載荷する方 式 (プレシオメーター，LLT 等) と，金属製の剛体載荷 板を孔壁の一部に押し付けて等変位に載荷させる方式 (Goodman Jack, KKT 等) とがある. 前者では境界条 件が単純であるため, 弾性解から容易に変形係数を算 定することができるが, 後者では図-1 のモデルに対し， 境界条件を区分的に与えなければならないので，解析 はやや複雑になる.

Goodman(1968) ${ }^{1)}$ はこのモデルに対し, Jaeger の 解 ${ }^{2)}$ を改良し， $x$ 軸方向に一定な応力分布を仮定した. これは孔壁の単位面積当たりにすると図-2(a)のよう な分布となるが, この条件より変位解 (Goodman 式) を求めた.この変位解は半径方向成分 $u_{r}$ であるが, Hustrulid $(1976)^{3)}$ はその後, 軸方向成分 $u_{x}$ を用いて 解を修正した. さらに Amadei ら (1985) ${ }^{4)}$ は図-2(b) のように, 軸方向応力を単位面積当たりで一定となる ように仮定して再修正している.これらの変位解 (算 定式) の違いによる変形係数算定表は西村 $(1993)^{5)}$ に よってまとめられている.

ボアホールジャッキ試験による荷重-変位関係 (K 值) を算定式に代入することによって求められる変形係数 の值は, Meyer(1974) らの実験6) によって真の值より も過小評価されることが指摘され，この要因を追求す るためにそれ以降の幾つかの研究がなされた. その結 果, Goodman Jackにおいて変形係数が過小評価され る主要因として 1) 載荷板の曲げによる見かけ変位量の 増加の影響7）や，2）孔壁の乱れや載荷板との曲率の不 一致による接触面積の减少 $\left.{ }^{8)} ， 3\right)$ 岩盤特有の不連続面

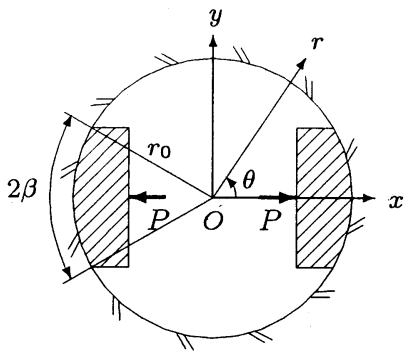

図一 1 ボアホールジャッキ

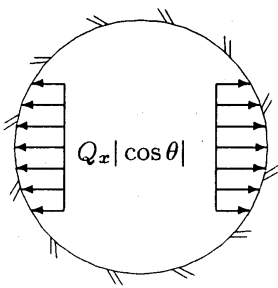

(a) Goodman の条件

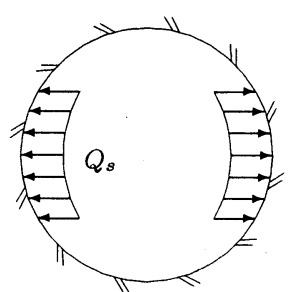

(b) Amadei の条件
図一２第一種境界条件

の影響9) が大きいことが指摘され，これらによる変形 係数の定量的な低減率が示された.

これら一連の研究の中では Goodman, Hustrulid お よび Amadei らの算定式が各々に使われているが，彼 らの行った理論解析は応力のみで境界条件を与える, い わゆる第一種境界值問題として位置付けられるもので あって, 得られる変位解は接触境界において一定とは ならない近似解である. 


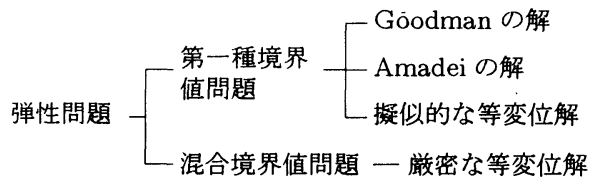

図-3 各解析理論の位置付け

このように理論解の精度的問題と前述 1) 3) の要因 とは別々に論じられ, しかも变形係数の評価には後者 の要因が大きいために, 変形係数の算定に関わる不確 定要因 (解析手法, 境界条件等)に対してはあまり厳密 な議論がなされてこなかった。

そもそも，接触境界で変位が一定でそれ以外の境 界で応力自由の条件を与えて解く問題は混合 (第三 種) 境界值問題と言われ, この条件下で得られた弾 性解が等変位解析の厳密解となる。この解析手法は Muskhelishvili(1953) ${ }^{11)}$ によって既に体系付けられて おり, 具体的な研究として, 妻木 $(1965)^{12)}$ や鎌田 $(1968)^{13)}$ らが等方性や異方性の無限弾性体を対象と して図-1 の問題が解かれている.

図-3 に本論文で扱う 4 通りの解析理論の位置付けを 示してあるが, 最終的に本研究では混合 (第三種) 境界 值問題での厳密解から，等変位条件における厳密な変 形係数算定式を提示することを目的とする.

第一種境界值問題としての解析は解析過程が比較的 簡便であり，近似的に弾性問題を解くものとしても有 用であるため, 従来の解析を整理しつつ, 境界応力分 布を改良した擬似的な等変位解を数值計算例とともに 提示寸るものとする.

応力とひずみの非線形性に関しては，ひずみの小さ い範囲では孔壁のゆるみや亀裂の閉合等によって, ま たひずみの大きい範囲では岩盤の塑性変形や破壊等に よって線形性が損なわれる.ここでは，これまでの評 価の対象であった線形の部分, 寸なわち擬似弾性域に ついて議論する14)。

\section{2. 第一種境界値問題による計算}

弾性論従って各解析理論を整理する，本論文で用い る主な記号は表-1 に定める. 符号は弾性学の規約に従 い, 引張応力を正とする.

\section{（1）Goodmanの境界条件}

油圧 $Q_{h}$ で載荷板を $x$ 軸方向に載荷したとき, 載荷 角度 $2 \beta$ の範囲において載荷板が孔壁に与える荷重と してGoodman は $\sigma_{x}$ が一定となる条件を仮定した. す
表一 1 本論文に用いる主な記号

\begin{tabular}{|c|c|c|}
\hline 記号 & 説 明 & 次元 \\
\hline$E$ & 岩盤弹性係数 (変形係数) & $F L^{-2}$ \\
\hline$G$ & 岩盤せん断弹性俰数 & $F L^{-2}$ \\
\hline$\nu$ & 岩盤のポアソン比 & 無次元 \\
\hline$\kappa$ & $3-4 \nu$ (平面ひずみ) & 無次元 \\
\hline$r, \theta$ & 極座標の動径, 中心角 & $L$, 無次元 \\
\hline$r_{0}$ & 孔半径 & $L$ \\
\hline$\beta$ & 載荷角度の半分 & $L$ \\
\hline$Q_{h}$ & 油圧 & $F L^{-2}$ \\
\hline$Q_{x}$ & 軸方向一定荷重 $\left(=\eta Q_{h}\right)$ & $F L^{-2}$ \\
\hline$Q_{s}$ & 接触面一定荷重 $\left(=\frac{\sin \beta}{\beta} Q_{x}\right)$ & $F L^{-2}$ \\
\hline$P$ & 載荷合力 & $F L^{-1}$ \\
\hline C & 3 次元補正係数 & 無次元 \\
\hline$\eta$ & 油圧損失係数 & 無次元 \\
\hline$\Delta Q_{h}$ & 油圧増分 & $F L^{-2}$ \\
\hline$\Delta \bar{u}_{r}$ & 孔壁の径方向平均変位增分 & $L$ \\
\hline$\Delta \bar{u}_{x}$ & 孔壁の軸方向平均変位増分 & $L$ \\
\hline$\Delta u_{x}$ & 軸方向変位増分 & $L$ \\
\hline
\end{tabular}

なわち,

$$
\sigma_{x}=\left\{\begin{array}{cc}
-Q_{x} & (|\theta| \leq \beta,|\theta-\pi| \leq \beta), \\
0 & \text { (上記以外の範囲). }
\end{array}\right.
$$

$\theta$ は図-1 に定める中心角で, $Q_{x}$ は軸方向一定荷重であ る.ここに，油圧ホースにおける油圧損失係数を $\eta$ と すると $Q_{x}=\eta Q_{h}$ の関係がある. $\eta$ は Goodman Jack で $0.93, \mathrm{KKT}$ で $0.97 \sim 0.98$ (深度 $30 \mathrm{~m}$ の場合) ${ }^{16)}$ であ る. $\sigma_{x}$ は境界の単位面積当たりにすると, 図-2(a)の 分布となる. この条件のもとで得られる半径方向の平 均変位 $\bar{u}_{r}$ の計算過程は付録 (1)に示したように, 式 (I.8)) で得られるが, これを変形して弾性係数 $E$ が次 式で得られる.

$$
E=C \eta r_{0} \frac{\Delta Q_{h}}{\Delta \bar{u}_{r}} \Phi(\nu, \beta) .
$$

ここに, $C: 3$ 次元補正係数, $r_{0}$ : ボア半径であり, $C$ は Goodman Jack で $0.86, \mathrm{KKT}$ (高圧型) でほぼ 1.0 とされている4),16). $\Phi(\nu, \beta)$ は岩盤のポアソン比 $\nu$ と $\beta$ の関数であり, $\kappa=3-4 \nu$ (平面ひずみ) として次式 で与えられる.

$$
\begin{array}{r}
\Phi(\nu, \beta)= \\
+\sum_{m=1}^{\infty} \frac{1+\nu}{\sin \beta}\left[\beta\left(1+\frac{\kappa}{2}\right) \sin \beta+\frac{\beta \kappa}{6} \sin 3 \beta\right. \\
\left.+\frac{\sin (2 m+1) \beta}{2 m+1}\right\}+\left(\frac{\kappa}{2 m+1}\left\{\frac{1}{2 m+1}+\frac{\kappa}{2 m-1}\right)\right. \\
\quad \times\left\{\frac{\sin (2 m+3) \beta}{2 m+1}+\frac{\sin (2 m-1) \beta}{2 m-1}\right\} \\
\left.\left.+\frac{1}{2 m-1}\left\{\frac{\sin (2 m-1) \beta}{2 m-1}+\frac{\sin (2 m-3) \beta}{2 m-3}\right\}\right]\right]
\end{array}
$$




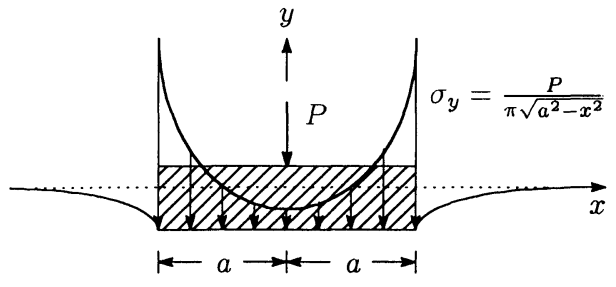

図-4 剛体接触問題

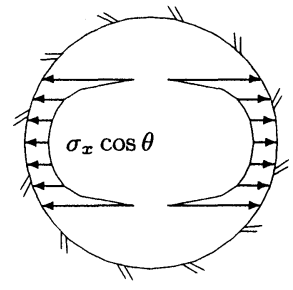

図一 5 擬似等変位条件

式 (2) および式 (3) を本論文では初期 Goodman 式と呼 ぶ. $\Phi(\nu, \beta)$ の值を数表化したものは Goodman 定数と して変形係数の算定に広く使われてきている1).

一方, Hustrulid は軸方向変位 $u_{x}$ から平均変位 $\bar{u}_{x}$ (付録の式(I.10)) を求め, 次の修正式を提示した ${ }^{3 h 5)}$.

$$
\begin{gathered}
E=C \eta r_{0} \frac{\Delta Q_{h}}{\Delta \bar{u}_{x}} \Phi(\nu, \beta), \\
\Phi(\nu, \beta)=\frac{2\left(1-\nu^{2}\right)}{\pi \sin \beta}\left[\left(\beta+\frac{\sin 2 \beta}{2}\right)^{2}\right. \\
\left.+\sum_{m=1}^{\infty} \frac{1}{2 m+1}\left\{\frac{\sin 2 m \beta}{2 m}+\frac{\sin 2(m+1) \beta}{2(m+1)}\right\}^{2}\right] .
\end{gathered}
$$

これを修正 Goodman 式と呼ぶ.

\section{(2) Amadei の境界条件}

Amadei は図-2(b) に示す境界の $x$ 方向の単位面積 当たりで一定となる応力分布を仮定した.これは軸方向 応力 $\sigma_{x}$ としては以下の分布になる.

$$
\sigma_{x}=\left\{\begin{array}{cc}
-\frac{Q_{s}}{|\cos \theta|} & (|\theta| \leq \beta,|\theta-\pi| \leq \beta), \\
0 & \text { (上記以外). }
\end{array}\right.
$$

ここに $Q_{s}$ は接触面一定荷重であり, 次の関係が成り 立つ.

$$
Q_{s}=\eta \frac{\sin \beta}{\beta} Q_{h} .
$$

この条件から求められた付録の式 (I.16)の $\bar{u}_{x}$ より, $\Phi(\nu, \beta)$ は次式で与えられる.

$$
\Phi(\nu, \beta)=\frac{8\left(1-\nu^{2}\right)}{\pi \beta^{2}} \sin \beta \sum_{m=1}^{\infty} \frac{\sin ^{2}(2 m-1) \beta}{(2 m-1)^{3}} .
$$

\begin{tabular}{c|c|c}
\hline \hline 機種 & $\begin{array}{c}\text { 孔直径 } \\
(\mathrm{mm})\end{array}$ & $\begin{array}{c}\text { 載荷角度 } \\
\boldsymbol{\beta}\left(^{\circ}\right)\end{array}$ \\
\hline Goodman Jack & 76 & $\mathbf{4 5}$ \\
高圧型 KKT & 66 & 27.5 \\
\hline \multicolumn{2}{|c}{}
\end{tabular}

この $\Phi(\nu, \beta)$ を用いた式 (4) の第一式を Amadei 式と 呼ぶ.

\section{(3) 擬似等変位条件}

Goodman および Amadei の境界条件は載荷板端部 での荷重応力 $\sigma_{x}$ が不足して等変位とはならない。こ の問題に類似する図-4に示すような半無限体と剛体の 接触問題は Muskhelishvili によって示されており, 合 力 $P$ で圧縮された幅 $2 a$ の接触面に発生する応力 $\sigma_{y}$ は, 図中に示すように端部 $(x= \pm a)$ で無限大に増大 する分布であることが示されている11)。

この結果を円孔境界に応用すれば, 軸方向応力 $\sigma_{x}$ を 次のような関数で与える.

$$
\sigma_{x}=\left\{\begin{array}{cc}
-\frac{P}{\pi r_{0} \cos \theta \sqrt{\beta^{2}-\theta^{2}}} & (|\theta| \leq \beta), \\
\frac{P}{\pi r_{0} \cos \theta \sqrt{\beta^{2}-(\theta-\pi)^{2}}} & (|\theta-\pi| \leq \beta), \\
0 & \text { (上記以外). }
\end{array}\right.
$$

ここに, 力の釣り合いから $P=2 r_{0} \sin \beta Q_{h}$ が成り立 つ. 境界上の単位面積当たりの応力分布は図-5 のよう になる.この条件から載荷範囲における平均変位 $\bar{u}_{x}$ は 付録中の式 (I.21) として得られ，これを変形すること によって式 (4)の $\Phi(\nu, \beta)$ が以下のように導かれる.

$$
\left.\begin{array}{l}
\Phi(\nu, \beta)=\frac{4(1+\nu)}{\pi^{2} \beta} \sin \beta \sum_{m=1}^{\infty} J_{m} \frac{\sin (2 m-1) \beta}{(2 m-1)^{2}}, \\
J_{m}=\int_{0}^{\beta}[\{\kappa \cos 2 m \theta+\cos 2(m-1) \theta\} \cos \theta \\
+\{\kappa \sin 2 m \theta-\sin 2(m-1) \theta\} \sin \theta] \frac{\cos \theta d \theta}{\sqrt{\beta^{2}-\theta^{2}}} .
\end{array}\right\}
$$

$J_{m}$ は数值積分によって求められる. この $\Phi(\nu, \beta)$ を用 いて算定した式 (4) の第一式を擬似等变位式と呼ぶこ とにする.

\section{3. 混合境界値問題}

前章までの第一種境界値問題においては，境界上で 等変位となる篇密な応力分布は演繹的な方法で見出さ 
ざるを得ない．これを順解析によって得るためには, 次 の混合境界条件を与えることが必要である.

$$
\begin{array}{cc}
\frac{\partial u_{x}}{\partial \theta}=\frac{\partial u_{y}}{\partial \theta}=0, & (|\theta| \leq \beta,|\theta-\pi| \leq \beta) \\
\sigma_{r}=\tau_{r \theta}=0, & (\text { 上記以外の境界上の点) } \\
\sigma_{r}=\sigma_{\theta}=\tau_{r \theta}=0, & (\text { 無限遠. } \therefore r \rightarrow \infty)
\end{array}
$$

ここに, $u_{x}, u_{y}:$ 孔壁変位の $x, y$ 方向成分, $\sigma_{r}, \tau_{r \theta}$ : 表面力の直応力, せん断応力成分である.

妻木・山田の研究12) によればこの条件下での変位解 は次の有限項で与えられる.

$$
\frac{2 G}{P} u_{x}=\frac{\kappa}{2} e^{\gamma \pi} \frac{J_{0}^{\prime}}{J_{0}}
$$

ここに,

$$
\begin{aligned}
& \gamma=\frac{\ln \kappa}{2 \pi} \\
& J_{0}=\int_{0}^{\beta} \frac{\cos \Theta_{1}}{r_{0} \sqrt{\sin ^{2} \beta-\sin ^{2} \theta}} d \theta \\
& J_{0}^{\prime}=\int_{\beta}^{\frac{\pi}{2}} \frac{\cos \Theta_{2}}{r_{0} \sqrt{\sin ^{2} \theta-\sin ^{2} \beta}} d \theta \\
& \Theta_{1}=\gamma \log \frac{\sin (\beta+\theta)}{\sin (\beta-\theta)} \\
& \Theta_{2}=\gamma \log \frac{\sin (\theta+\beta)}{\sin (\theta-\beta)} .
\end{aligned}
$$

載荷板変位量は平均変位をとる必要がなく, 算定式 は次のように得られる.

$$
\left.\begin{array}{rl}
E & =C \eta r_{0} \frac{\Delta Q_{h}}{\Delta u_{x}} \Phi(\nu, \beta), \\
\Phi(\nu, \beta) & =\kappa(1+\nu) \sin \beta e^{-\gamma \pi} \frac{J_{0}^{\prime}}{J_{0}} .
\end{array}\right\}
$$

これを厳密等変位式と名付ける.

\section{4. 数值計算例}

応力は付録の式(I.2), 式(II.1)によって求められる. Goodman 解及び Amadei 解では級数を 100 項程度採 用すれば十分収束した值が得られるが，擬似等変位解 (以後, 擬似解) では $\theta=\beta$ での特異性によって収束性 がやや悪くなることを考慮し, 最終的に三種の近似解 では 200 項採用して比較することにした.

近似解の変位は式 (I.3)によって求められるが, 応力 やひずみよりも関数のオーダーがーつ高いため級数の 収束性の影響はあまり受けない。したがって, 応力解 析の場合ほど項数を採らなくとも安定した值が得られ, ここでは 100 項とした.

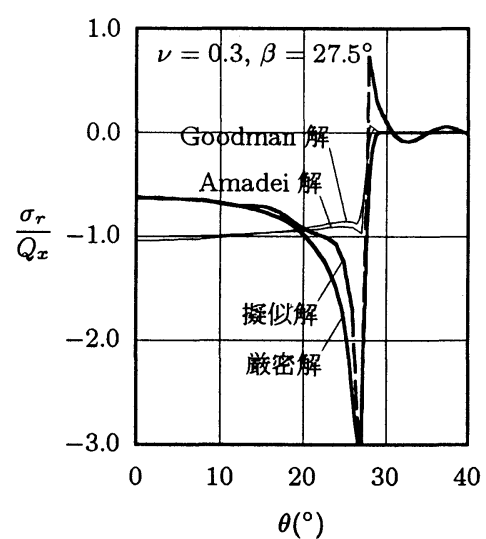

(a) 半径方向直応力 $\sigma_{r}$ の分布

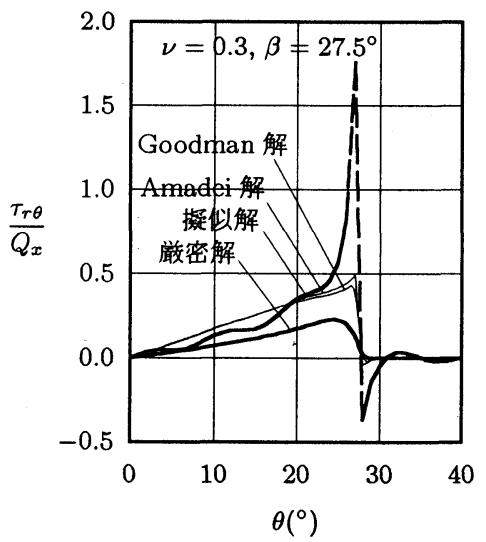

(b) せん断応力 $\tau_{r \theta}$ の分布

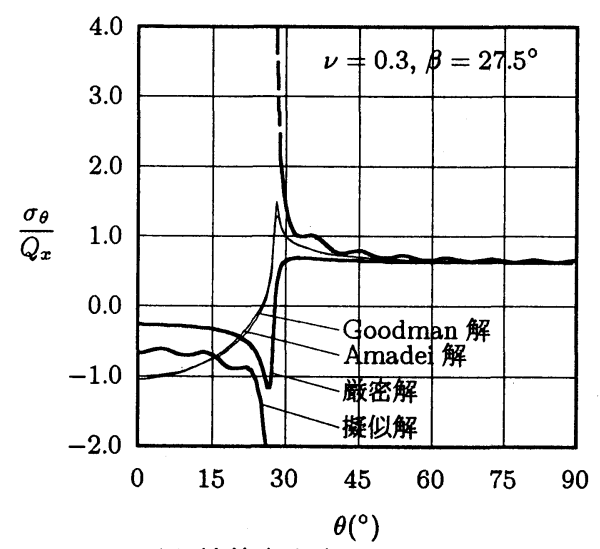

(c) 接線方向応力 $\sigma_{\theta}$ の分布

图ー 6 ボアホール境界上の忘力 (KKT)

また, 擬似解や厳密解による解析では式 (9), (12)に おいて台形公式を用た数値積分を実施した. 刻み角度 は区間上限 $(\theta=\beta)$ 付近を除く範囲でを10程度とすれ ば十分であることが確認されたが，上限值付近での関 


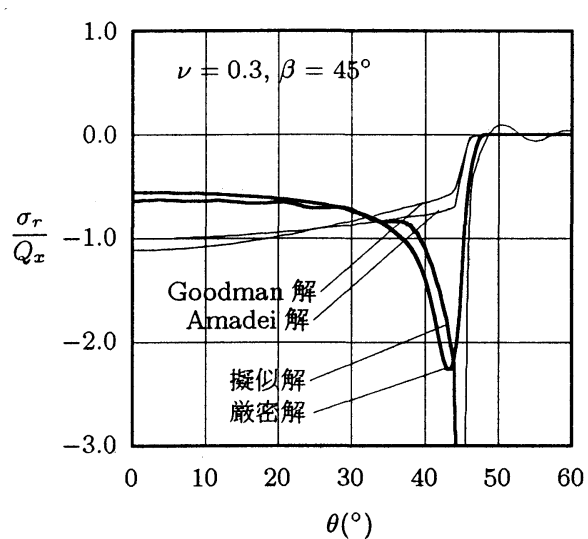

(a) 半径方向直応力 $\sigma_{r}$ の分布

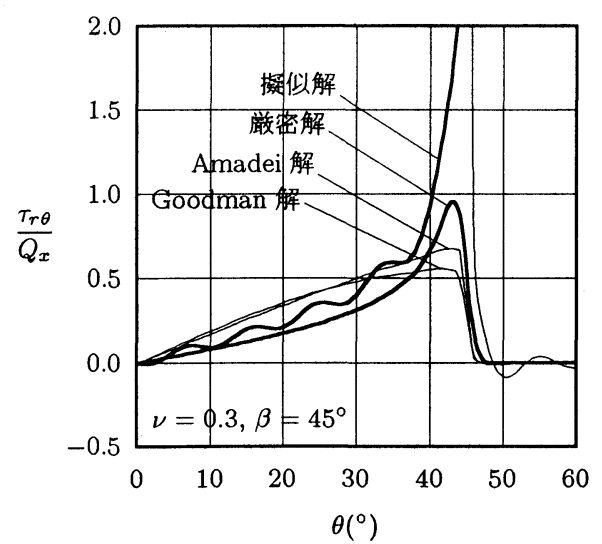

(b) せん断応力 $\tau_{r \theta}$ の分布

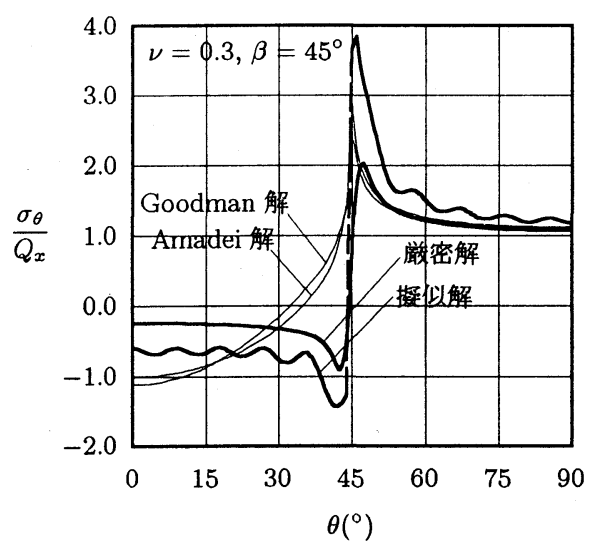

(c) 接線方向応力 $\sigma_{\theta}$ の分布

図ー 7 ボアホール境界上の応力 (Goodman Jack)

数值を詳細に把握するために全体に $0.05^{\circ}$ とした.

なお，載荷角度 $\beta$ は表-2 に示寸国内外における主要 2 機種の值を使用し, 基準の応力には式 (1)の $Q_{x}$ を採 用した.

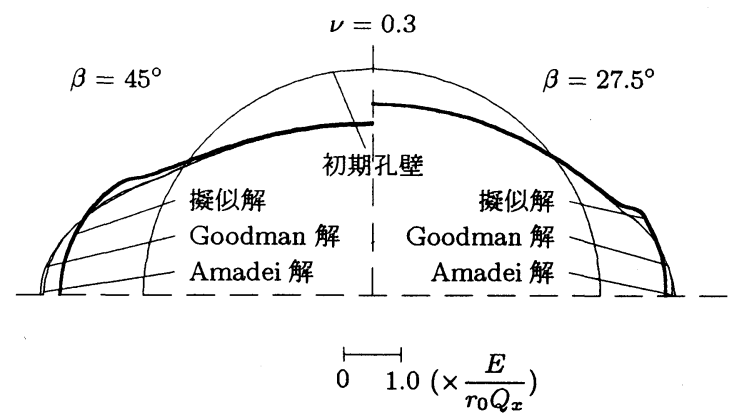

図-8 ボアホールの変形

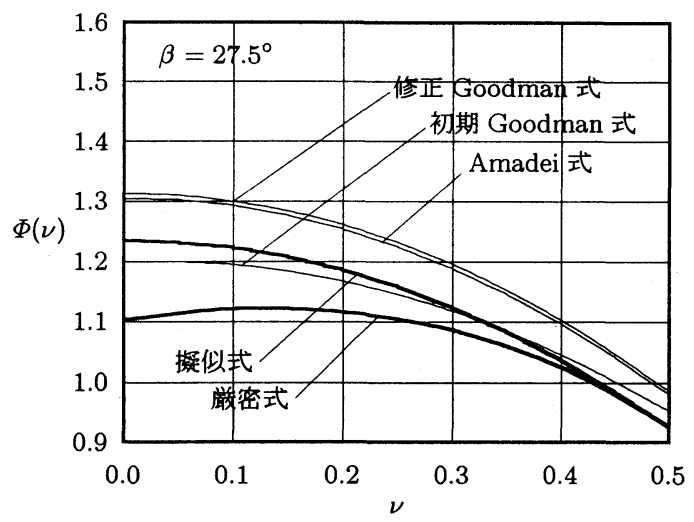

(a) $\mathrm{KKT}$

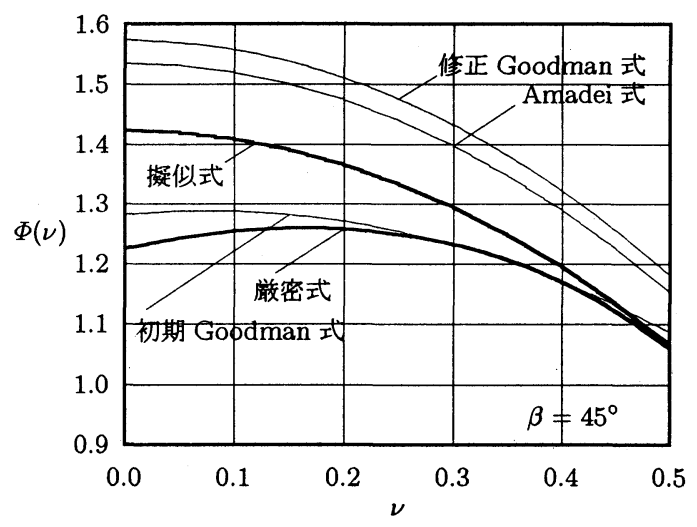

(b) Goodman Jack

图- 9 算定係数の比較

\section{(1) 応力解析}

まず, $\nu=0.3, \beta=27.5^{\circ}$ (KKT) の場合のボアホー 儿境界上の応力分布を図一6 に示す.

図 (a)の半径方向主応力 $\sigma_{r}$ は擬似解と厳密解はよく 一致し, 載荷端部 $(\theta=\beta)$ で圧縮の応力集中が生じて いる. Goodman と Amadei の解は載荷中央から端部の 值をほぼ平均化した分布図となっている. 図 (b) の接 
線方向のせん断応力 $\tau_{r \theta}$ は厳密解による応力が最も小 さく, 三種の近似解による分布とは明瞭な違いが認め られる。

図 (c) の接線方向直応力 $\sigma_{\theta}$ は, 接触面 $(\theta \leq \beta)$ にお いては三種の近似解応力は厳密解応力とは異なった分 布を示している. 特に, Goodman 及びAmadei の分布 と厳密解分布とでは端部 $(\theta=\beta)$ における応力集中の 正負が逆である.

次に, $\nu=0.3, \beta=45^{\circ}$ (Goodman Jack) の場合の 同様の計算結果を図-7 に示す. 図 (a) の $\sigma_{r}$ の分布は $\beta=27.5^{\circ}$ の場合と傾向は変わらないが, 応力集中度は やや減少している. 載荷角度が大きくなったために, 図 (b) の $\tau_{r \theta}$ は端部での厳密解の応力集中度が Goodman と Amadei の近似解よりも大きくなっている.

図 (c) の $\sigma_{\theta}$ の厳密解分布では, 接触境界側の端部 付近における圧縮応力の集中度が $\beta=27.5^{\circ}$ の場合 に比べてやや小さくなっているが, 自由境界側端部で $\beta=27.5^{\circ}$ の場合には見られなかった応力集中が生じ ている. 三種の近似解による応力は $\beta=27.5^{\circ}$ の場合 と同様の傾向である. 図 (b),(c) における擬似解の応力 はいくらか振動した分布となっており, 項数が 200 の この場合では他の二つの近似解に比べ収束性がやや悪 いことを示している.

\section{(2) 孔壁変形と変形係数算定係数}

図-8に $\beta=27.5^{\circ}, 45^{\circ}$ の場合の 3 種の近似解による ボアホールの孔壁変位を示す.この図によれば Goodman と Amadei の解では, 載荷軸 ( $x$ 軸) 方向と直交方 向 ( $y$ 軸) の変位成分が生じているのが分かる. 擬似解 では載荷端部で変位量が急変しており, 本来の等変位 の状態に近い.

図-9には算定係数 $\Phi(\nu, \beta)$ ををパラメータとして 示す. 図 (a) の $\beta=27.5^{\circ}$ では, 厳密等変位式による值 が最小で, 初期 Goodman 式と擬似等変位式がこれに 最も近い. 修正 Goodman 式と Amadei 式の值の差は $1 \%$ 末満である. 図 (b) $\beta \beta=45^{\circ}$ では修正 Goodman 式およびAmadei 式と厳密等変位式による值の差は $\beta=$ $27.5^{\circ}$ の場合よりも桩大するが, 初期 Goodman 式の值 は厳密等変位式の值に近づいている. 㛜密等変位式の $\nu=0.25$ における 1.250 は Goodmanの示した FEM 解析結果と一致している1).

\section{(3) 考察}

数値計算によって得られた知見を以下にまとめる.

- 近似解では軸方向成分の荷重応力のみを表示して いるに過ぎず，完全に境界応力を再現することは できない.
- 自由今日海面における接線方向の引張応力 $\sigma_{\theta}$ は 図-6(c), 図-7(c) によれば一定もしくは端部付近 で最小となる.このため載荷荷重による引張亀裂 の発生に対する検討は, $\beta=45^{\circ}$ (Goodman Jack) の場合には $\theta=90^{\circ}$ ( $y$ 軸上) における応力值のみ から行うだけでは不十分である.

- Goodman と Amadei の境界条件の違いは応力・変 位の解析にほとんど差をもたらさないが, 端部付 近での忘力集中による岩盤の降伏や引張亀裂の発 生を詳細に検討することはできない..

- 擬似似等変位条件による応力解析は他の二つの近 似解よりも収束性が劣るものの, 変位解析では擬 似等変位条件が三種の近似解の中で最も等変位条 件に近い結果を与える.

-図-9 によれば, $0.1 \leq \nu \leq 0.4$ の範囲では初期 Goodman 式による $\Phi(\nu, \beta)$ が厳密等変位式のそれ に最も近い. これは, Goodman やAmadei の解で は載荷軸方向と直交する方向に変位成分 $u_{y}$ を生 じるが (図-8), 平均変位としては載荷軸方向の変 位成分 $u_{x}$ のみを用いるため, 最終的に計算され る変位増分 $\Delta \bar{u}_{x}$ は小さくなってしまうためであ る.このことは逆に式 (4)における平均変位は式 (2) と同様に $\Delta \bar{u}_{r}$ とするべきであることを示唆し ている.

また, 第一種境界値問題における三種の近似解は項数 を十分多く採ることによって収束性は高まるが, Fourier 級数を用いている性質上，区間境界 (載荷端部) 付近で は $2 \%$ 程度の誤差が残存する (Gibbs の現象). FEM 解 析においても，同様の箇所における要素分割の仕方が 計算精度全体に与える影響は当然大きいと考えられる. これに対し, 厳密解を用いる場合には数值積分が伴う ものの，刻み幅に注意しさえすればその他の計算上の 制約条件がなく，同箅所における分布を正確に得るこ とが出来る.

さらに, この弾性解析では載荷板が孔壁に完全密着 していることを前提としているが，そのためには，せ ん断応力 $\tau_{r \theta}$ の大きさが 直応力 $\sigma_{r}$ の大きさに対して ある一定值以下となり，載荷板が滑動しないことが必 要である.すなわち，載荷板と岩盤孔壁との摩擦係数 を $\mu$ とすれば, $\sigma_{r} \geq \tau_{r \theta} / \mu$ が完全密着の条件である.

色部ら ${ }^{15)}$ によれば， $\mu$ は少なくとも 0.5 以上だとし ているが，いま仮にそうだとして図-6(a),(b) および図$7(\mathrm{a}),(\mathrm{b})$ の厳密解による結果を吟味すると, $\beta=27.5^{\circ}$ の場合では上の条件はほほ満足されるが, $\beta=45^{\circ}$ の場 合では端部付近で必ずしも満足しないことが分かった。 
表一 3 算定係数 $\Phi(\nu, \beta)$ の比較

\begin{tabular}{|c|c|c|c|c|c|c|}
\hline \multirow[b]{2}{*}{$\nu$} & \multicolumn{3}{|c|}{$\beta=27.5^{\circ}$} & \multicolumn{3}{|c|}{$\beta=45^{\circ}$} \\
\hline & (1) & (2) & (2)/(1) & (1) & (2) & (2)/(1) \\
\hline 0.10 & 1.194 & 1.121 & 0.94 & 1.288 & 1.254 & 0.97 \\
\hline 0.15 & 1.184 & 1.122 & 0.95 & 1.282 & 1.260 & 0.98 \\
\hline 0.20 & 1.168 & 1.117 & 0.96 & 1.271 & 1.259 & 0.99 \\
\hline 0.25 & 1.146 & 1.105 & 0.96 & 1.254 & 1.250 & 1.00 \\
\hline 0.30 & 1.118 & 1.087 & 0.97 & 1.232 & 1.233 & 1.00 \\
\hline 0.35 & 1.085 & 1.061 & 0.98 & 1.204 & 1.208 & 1.00 \\
\hline 0.40 & 1.047 & 1.026 & 0.98 & 1.171 & 1.171 & 1.00 \\
\hline
\end{tabular}

\section{5. 結 言}

国内では, ボアホールジャッキ試験から変形特性を求 める場合, 初期 Goodman 式によって変形係数の算定 を行うことが多いが，この代わりに厳密等変位式を用 いるとすれば，表-3より最大でも $\beta=27.5^{\circ}(\mathrm{KKT})$ で $6 \%, \beta=45^{\circ}$ (Goodman Jack) で $3 \%$ 過小に計算され る程度の差異である.したがって，初期 Goodman 式を 用いてこれまでに評価されてきた変形係数の值は結果 的にほとんど修正される必要はないが，今後解析理論 としては厳密解を適用していくことがふさわしく, 変 形係数の算定には表-3 の(2) の值を採用することが望 ましい.

謝辞 : 本研究をまとめるにあたり，山梨大学工学部の 平嶋健一教授には理論的な面で御指導いただいた。 ま た，川崎地質 (株) の宮川純一氏，黛廣志氏，村山英司 氏からは実務的な観点から幾つかの御助言をいただく とともに，研究に割く時間を快く与えて下さった.こ れらの方々に対し，ここに深く感謝する次第である.

\section{付録 I 第一種境界値問題による計算式}

孔の表面応力を次のように Fourier 級数展開する.

$\sigma_{r}-i \tau_{r \theta}=a_{0}+\sum_{m=1}^{\infty}\left(a_{m} \cos 2 m \theta-i b_{m} \sin 2 m \theta\right)$.

この式に対し, Muskhelishvill の定義する複素応力関数 から導かれる応力算定式とを比較することによって, 極 座標における応力の各成分は Fourier 係数 $a_{m}(m \geq 0)$, $b_{m}(m \geq 1)$ を用いて最終的に次式で表される.

$$
\begin{aligned}
\sigma_{r}= & a_{0} \rho^{2}+\sum_{m=1}^{\infty} \rho^{2 m}\left\{\left(1+m-m \rho^{2}\right) a_{m}\right. \\
& \left.-\left(1+m-\rho^{2}-m \rho^{2}\right) b_{m}\right\} \cos 2 m \theta,
\end{aligned}
$$

$$
\begin{array}{r}
\sigma_{\theta}=-a_{0} \rho^{2}+\sum_{m=1}^{\infty} \rho^{2 m}\left\{\left(1-m+m \rho^{2}\right) a_{m}\right. \\
\left.-\left(1-m+\rho^{2}+m \rho^{2}\right) b_{m}\right\} \cos 2 m \theta \\
\tau_{r \theta}=\sum_{m=1}^{\infty} \rho^{2 m}\left\{m\left(1-\rho^{2}\right) a_{m}\right. \\
\left.-\left(m-\rho^{2}-m \rho^{2}\right) b_{m}\right\} \sin 2 m \theta .
\end{array}
$$

ここに, $\rho=r_{0} / r$ である. 孔壁上 $(\rho=1)$ の変位成分 は次式によって求められる.

$$
\left.\begin{array}{l}
\frac{2 G}{r_{0}} u_{x}=-a_{0} \cos \theta-\frac{1}{2} \sum_{m=1}^{\infty}\left\{\kappa\left(a_{m}-b_{m}\right) \times\right. \\
\left.\frac{\cos (2 m-1) \theta}{2 m-1}+\left(a_{m}+b_{m}\right) \frac{\cos (2 m+1) \theta}{2 m+1}\right\}, \\
\frac{2 G}{r_{0}} u_{y}=-a_{0} \sin \theta+\frac{1}{2} \sum_{m=1}^{\infty}\left\{\kappa\left(a_{m}-b_{m}\right) \times\right. \\
\left.\frac{\sin (2 m-1) \theta}{2 m-1}-\left(a_{m}+b_{m}\right) \frac{\sin (2 m+1) \theta}{2 m+1}\right\} .
\end{array}\right\}
$$

\section{（1）Goodmanの境界条件}

載荷範囲における $\sigma_{\boldsymbol{x}}$ を表面応力成分に分解すると， 次のようになる.

$$
\left.\begin{array}{l}
\sigma_{r}=-Q_{x} \cos ^{2} \theta, \\
\tau_{r \theta}=\frac{Q_{x}}{2} \sin 2 \theta .
\end{array}\right\}(|\theta| \leq \beta,|\theta-\pi| \leq \beta)
$$

この条件に対し, Fourier 係数は次式で与えられる.

$$
\left.\begin{array}{l}
a_{0}=-\frac{Q_{x}}{2 \pi}(2 \beta+\sin 2 \beta), \\
a_{1}=-\frac{Q_{x}}{\pi}\left(\beta+\sin 2 \beta+\frac{1}{4} \sin 4 \beta\right), \\
b_{1}=\frac{Q_{x}}{\pi}\left(\beta-\frac{1}{4} \sin 4 \beta\right), \\
(m \geq 2) \\
a_{m}=-\frac{Q_{x}}{\pi}\left\{\frac{\sin 2 m \beta}{m}+\frac{\sin 2(m-1) \beta}{2(m-1)}\right. \\
\left.\quad+\frac{\sin 2(m+1) \beta}{2(m+1)}\right\}, \\
b_{m}=\frac{Q_{x}}{\pi}\left\{\frac{\sin 2(m-1) \beta}{2(m-1)}-\frac{\sin 2(m+1) \beta}{2(m+1)}\right\} .
\end{array}\right\}
$$

これを式 (I.2) に代入すると極座標での応力成分が得ら れる. また, 式(I.3) に代入して境界変位 $u_{r}$ は以下の 
ようになる.

$$
\begin{array}{r}
\frac{2 \pi G}{r_{0} Q_{h}} u_{r}=\beta(1+\kappa \cos 2 \theta)+\sum_{m=1}^{\infty} \frac{\sin 2 m \theta}{2 m} \\
\left\{\kappa \frac{\cos 2(m+1) \theta}{2 m+1}+\kappa \frac{\cos 2 m \theta}{2 m-1}+\frac{\cos 2 m \theta}{2 m+1}\right. \\
\left.+\frac{\cos 2(m-1) \theta}{2 m-1}\right\} .
\end{array}
$$

載荷範囲において平均変位 $\bar{u}_{r}$ を次式,

$$
\bar{u}_{r}=\int_{0}^{\beta} u_{r} r_{0} \cos \theta d \theta / \int_{0}^{\beta} r_{0} \cos \theta d \theta
$$

\section{によって求めると以下のようになる.}

$$
\begin{array}{r}
\frac{2 \pi G}{r_{0} Q_{h}} \sin \beta \bar{u}_{r}=\beta\left(1+\frac{\kappa}{2}\right) \sin \beta+\frac{\beta \kappa}{6} \sin 3 \beta \\
+\sum_{m=1}^{\infty} \frac{\sin 2 m \beta}{4 m}\left[\frac { \kappa } { 2 m + 1 } \left\{\frac{\sin (2 m+3) \beta}{2 m+3}\right.\right. \\
\left.+\frac{\sin (2 m+1) \beta}{2 m+1}\right\}+\left(\frac{1}{2 m+1}+\frac{\kappa}{2 m-1}\right) \\
\times\left\{\frac{\sin (2 m+1) \beta}{2 m+1}+\frac{\sin (2 m-1) \beta}{2 m-1}\right\} \\
+\frac{1}{2 m+1}\left\{\frac{\sin (2 m-1) \beta}{2 m-1}+\frac{\sin (2 m-3) \beta}{2 m-3}\right\}
\end{array}
$$

一方, $u_{x}$ は次式となる.

$$
\begin{aligned}
& \frac{2 \pi G}{r_{0} Q_{h}} u_{x}=(1+\kappa)\left[\beta \cos \theta+\sum_{m=1}^{\infty} \frac{\sin 2 m \theta}{2 m}\right. \\
& \left.\times\left\{\frac{\cos (2 m-1) \theta}{2 m-1}+\frac{\cos (2 m+1) \theta}{2 m+1}\right\}\right] .
\end{aligned}
$$

これを式(I.7)の $u_{r}$ の代わりに代入すると, 次式が得 られる。

$$
\begin{gathered}
\frac{2 \pi G}{r_{0} Q_{h}} \sin \beta \bar{u}_{x}=2(1-\nu)\left[\left(\beta+\frac{\sin 2 \beta}{2}\right)^{2}\right. \\
\left.\quad+\sum_{m=1}^{\infty}\left\{\frac{\sin 2 m \beta}{2 m}+\frac{\sin 2(m+1) \beta}{2(m+1)}\right\}^{2}\right] .
\end{gathered}
$$

\section{(2) Amadei の境界条件}

載荷範囲において $\sigma_{x}$ を極座標に変換すると以下の ようになる。

$$
\begin{gathered}
\sigma_{r}=-Q_{s}|\cos \theta|, \quad(\theta|\leq \beta,| \theta-\pi \mid \leq \beta) . \\
\tau_{r \theta}=\left\{\begin{aligned}
Q_{s} \sin \theta & (|\theta| \leq \beta), \\
-Q_{s} \sin \theta & (|\theta-\pi| \leq \beta),
\end{aligned}\right.
\end{gathered}
$$

このとき, Fourier 係数は以下の通りである.

$$
\begin{aligned}
& a_{0}=-\frac{2 Q_{s}}{\pi} \sin \beta, \\
& (m \geq 1), \\
& a_{m}=-\frac{2 Q_{s}}{\pi}\left\{\frac{\sin (2 m-1) \beta}{2 m-1}+\frac{\sin (2 m+1) \beta}{2 m+1}\right\}, \\
& b_{m}=\frac{2 Q_{s}}{\pi}\left\{\frac{\sin (2 m-1) \beta}{2 m-1}-\frac{\sin (2 m+1) \beta}{2 m+1}\right\} .
\end{aligned}
$$

式(I.13) を式(I.3) に代入して変位 $u_{x}$ は次式となる.

$$
\frac{2 \pi G}{r_{0} Q_{s}} u_{x}=2(1+\kappa) \sum_{m=1}^{\infty} \frac{\sin (2 m-1) \beta}{(2 m-1)^{2}} \cos (2 m-1) \theta .
$$

平均変位を次式 (I.15) で定義すると, 式 (I.16) が得ら れる.

$$
\begin{gathered}
\bar{u}_{x}=\int_{0}^{\beta} u_{x} r_{0} d \theta / \int_{0}^{\beta} r_{0} d \theta . \\
\frac{2 \pi G}{r_{0} Q_{s}} \bar{u}_{x}=\frac{2}{\beta}(1+\kappa) \sum_{m=1}^{\infty} \frac{\sin ^{2}(2 m-1) \beta}{(2 m-1)^{3}} .
\end{gathered}
$$

\section{(3) 擬似等变位条件}

載荷範囲において表面応力は次のように表される.

$$
\begin{gathered}
\sigma_{r}=\left\{\begin{array}{cc}
-\frac{P \cos \theta}{\pi r_{0} \sqrt{\beta^{2}-\theta^{2}}} & (|\theta| \leq \beta), \\
\frac{P \cos \theta}{\pi r_{0} \sqrt{\beta^{2}-(\theta-\pi)^{2}}} & (|\theta-\pi| \leq \beta) .
\end{array}\right. \\
\tau_{r \theta}=\left\{\begin{array}{cc}
\frac{P \sin \theta}{2 \pi r_{0} \sqrt{\beta^{2}-\theta^{2}}} & (|\theta| \leq \beta), \\
-\frac{P \sin \theta}{2 \pi r_{0} \sqrt{\beta^{2}-(\theta-\pi)^{2}}} & (|\theta-\pi| \leq \beta) .
\end{array}\right.
\end{gathered}
$$

Fourier 係数は次の積分形式で与えられる.

$$
\begin{aligned}
& a_{0}=-\frac{2 P}{\pi^{2} r_{0}} \int_{0}^{\beta} \frac{\cos \theta}{\sqrt{\beta^{2}-\theta^{2}}} d \theta \\
& (m \geq 1) \\
& a_{m}=-\frac{4 P}{\pi^{2} r_{0}} \int_{0}^{\beta} \frac{\cos \theta}{\sqrt{\beta^{2}-\theta^{2}}} \cos 2 m \theta d \theta \\
& b_{m}=\frac{4 P}{\pi^{2} r_{0}} \int_{0}^{\beta} \frac{\sin \theta}{\sqrt{\beta^{2}-\theta^{2}}} \sin 2 m \theta d \theta
\end{aligned}
$$

これより変位は次式となる.

$$
\frac{\pi^{2} G}{P} u_{x}=\sum_{m=1}^{\infty} J_{m} \frac{\cos (2 m-1) \theta}{2 m-1} .
$$


式 (I.15) から平均変位は最終的に次式となる.

$$
\frac{\pi^{2} G}{P} \bar{u}_{x}=\frac{1}{\beta} \sum_{m=1}^{\infty} J_{m} \frac{\sin (2 m-1) \beta}{(2 m-1)^{2}} .
$$

\section{付録 II 混合境界值問題での計算式}

混合境界値問題における接触境界 $(|\theta| \leq \beta,|\theta-\pi| \leq$ $\beta)$ での応力成分は次式で得られる.

$$
\left.\begin{array}{rl}
\sigma_{r} & =\frac{-P \cos \left(\Theta_{1}-\theta\right)}{2 J_{0} \sqrt{\sin ^{2} \beta-\sin ^{2} \theta}}, \\
\sigma_{\theta} & =\frac{\nu}{1-\nu} \sigma_{r}, \\
\tau_{r \theta} & =\frac{-P \sin \left(\Theta_{1}-\theta\right)}{2 J_{0} \sqrt{\sin ^{2} \beta-\sin ^{2} \theta}} .
\end{array}\right\}
$$

自由境界では次式となる.

$$
\left.\begin{array}{l}
\sigma_{\theta}=\frac{-2 \kappa e^{-\gamma \pi} P \sin \left(\Theta_{2}-\theta\right)}{(1+\kappa) J_{0} \sqrt{\sin ^{2} \theta-\sin ^{2} \beta}}, \\
\sigma_{r}=\tau_{r \theta}=0 .
\end{array}\right\}
$$

\section{参考文献}

1) Goodman,R.E., Van, T.K. and Heuze, F.E.: Mesurement of Rock Deformability in Boreholes, Proc.10th Symp. on Rock Mech., Univ. of Texas at Austin, 1968, Basic and Applied Rock Mechanics, pp.523-553, 1972.

2) Jaeger,J.C. \& Cook, N.G.W. : Fundamentals of Rock Mechanics, pp.242-245, Methuen \& Co.Ltd., 1969.

3) Hustrulid,W.A. : An analysis of the Goodman jack, Proc. 17th U.S Symp. on Rock Mech., Snowbird, Utah; Univ. of Utah, Salt Lake City, Utah Eng. Experiment Station, pp.4B10-1-4B10-8, 1976.
4) Heuze,F.E. \& Amadei, B.: The NX-Borehole Jack: A lesson in Trials and Errors, Int.J.Rock Mech.Min.Sci.\&Geomech.Abstr., Vol.22, No.2, pp.105-112, 1985.

5) 西村正夫 : ボアホールジャッキ試験による岩盤変形係数 の算定, 奥村組研究年報, No.19, pp.1-6, 1993.

6) Meyer,T.O. and Mcvey,J.R.: NX borehole jack modulus determinations in homogeneous, isotropic, elastic materials, USBM RI 7855, 1974.

7) Heuze,F.E. and Salem,A.: Plate bearing and borehole jack tests in rock - a finite element analysis, Proc. 17th U.S. Symp. on Rock Mechanics, Snowbird, Utah ; Univ. of Utah, Salt Lake City, pp.4B8-1-4B8-6, 1976.

8) Shuri,F.S.: Borehole diameter as a factor in borehole jack results, Proc.22nd U.S. Symp. on Rock Mechanics, Cambridge, Massachusetts, MIT Press, Cambridge, pp.392-397, 1981.

9) 苅谷敬三, 畠昭治郎, 谷本親伯:数值解析による等変位 方式孔内載荷試験の評価, 第 37 回年次学術講演会講演 概要集, 土木学会, pp.643-644, 1982.

10) 谷本親伯, 岸田 潔, 岡村正典:孔内載荷試験による岩 盤不連続面剛性の決定, 第 26 回土質工学研究発表会, pp.1147-1150, 1991.

11) Muskhelishvili,N.I.: Some basic problems of the mechanical theory of elasticity, Noordhoff, Groningen, 4th. ed., 1954.

12）妻木義彦, 山田哲義 : 1 円孔を有する無限板の二, 三の弾 性混合境界值問題, 機械学会論文集, 31-232, pp.1786$1792,1965$.

13）鎌田武司：だ円孔を有する異方性無限板の二次元混合境 界値問題, 機械学会論文集, 34-261, pp.801-810, 1968.

14) 三木幸蔵 : わかりやすい岩石と岩盤の知識, pp.247-286, 鹿島出版会, 1978 .

15）色部 誠, 川村泰資 : 孔内載荷試験による岩盤定数の測 定, 第 14 回岩盤力学に関するシンポジウム講演概要集, 土木学会, pp.1-5, 1982.

16) 三木幸蔵, 宮川純一：ボアホールジャッキ試験による岩 盤変形試験, 第 11 回岩盤力学に関するシンポジウム講 演概要集, 土木学会, pp.31-35,1978.

17) Timoshenko,S.P. and Goodier,N.E.: 弾性論 (第三版), pp.99-112, コロナ社, 1973.

18）森口繁一：2 次元弾性論，岩波書店, 1957.

19) 土木学会岩盤力学委員会：孔内載荷試験法の現状と課 題一指針化の試み一, pp.76-81, 1988.

(1999.8.24 受付)

\title{
EVALUATION OF ROCK MASS DEFORMABILITY BY ELASTIC EXACT SOLUTION IN BOREHOLE JACK TEST
}

\author{
Shohhei KAWAKUBO and Noriyuki YUKI
}

Estimation formula for rock mass deformability in borehole jack test initially derived by Goodman has been modified by Hustrulid and Amadei et al. But their solitions are approximately obtained as the first fundamental problem. This paper presents formula from the exact solution by the mixed fundamental problem. In the latter half, Numerical calculation by their approximate and our exact solutions are performed and quantitative differences between them are shown by graphical representation. 